\title{
Worker Protection Standard: Records of Employee Safety Training ${ }^{1}$
}

\author{
Frederick M. Fishel ${ }^{2}$
}

\section{Background}

In 1992, the US Environmental Protection Agency (EPA) issued a comprehensive regulation called the Worker Protection Standard for Agricultural Pesticides (WPS). The WPS covers pesticides used in the outdoor and enclosed-space production of plants on farms, forests, and nurseries, as well as greenhouses. The WPS requires agricultural employers to take steps to reduce pesticide-related risks when agricultural workers and pesticide handlers are exposed to these pesticides. The EPA has made several changes to the WPS since it was fully implemented in 1995. On November 2, 2015, the EPA revised the WPS, making significant changes to the rule's requirements. In late 2016, the EPA released the revised "How to Comply" manual to provide an updated resource. The entire document is posted on their website at https://www.epa.gov/pesticide-worker-safety/pesticideworker-protection-standard-how-comply-manual. Most of the revised provisions became effective January 2, 2017; there are four provisions that were delayed until January 2 , 2018. This document will address maintaining records of worker and handler training under the revised WPS.

\section{Pesticide Safety Training}

All workers and handlers employed by an agricultural employer must receive annual WPS training as a worker or as a handler. Employees must receive WPS training before they perform any worker or handler task on the establishment.

\section{Training Records}

Prior to the WPS revision in 2015, EPA would issue employee training verification cards; however, EPA no longer supplies or issues WPS training verification cards. It is now the responsibility of the employer to make a record of the training. Training records for each worker and handler must be kept on the establishment for 2 years from the date of training. The training record must include:

- The worker's or handler's printed name and signature

- The date of training

- The trainer's name

- Evidence of the trainer's qualification to train

- The employer's name

- Information to identify which EPA-approved training materials were used for the training (i.e., the EPA document number or EPA approval number for the materials).

WPS trainers are not required to provide each person trained with a copy of the training record. However, they must provide the record if the trained employee requests it. Individual training record forms or other methods of maintaining the required training information may be

1. This document is PI283, one of a series of the Agronomy Department, UF/IFAS Extension. Original publication date September 2019. Visit the EDIS website at https://edis.ifas.ufl.edu for the currently supported version of this publication.

2. Frederick M. Fishel, professor, Agronomy Department, and director, Pesticide Information Office; UF/IFAS Extension, Gainesville, FL 32611.

Use pesticides safely. Read and follow directions on the manufacturer's label.

The Institute of Food and Agricultural Sciences (IFAS) is an Equal Opportunity Institution authorized to provide research, educational information and other services only to individuals and institutions that function with non-discrimination with respect to race, creed, color, religion, age, disability, sex, sexual orientation, marital status, national origin, political opinions or affiliations. For more information on obtaining other UF/IFAS Extension publications, contact your county's UF/IFAS Extension office. U.S. Department of Agriculture, UF/IFAS Extension Service, University of Florida, IFAS, Florida A \& M University Cooperative Extension Program, and Boards of County Commissioners Cooperating. Nick T. Place, dean for UF/IFAS Extension. 
developed and used to meet this requirement. A suggested record, containing all the necessary elements, is found in Table 1. Additional information on worker and handler training is in https://edis.ifas.ufl.edu/pi268.

\section{Additional Information}

Fishel, F. M. 2015. A Summary of Revisions to the Worker Protection Standard - 2015. PI-261. Gainesville: University of Florida Institute of Food and Agricultural Sciences.

https://edis.ifas.ufl.edu/pi261.

Fishel, F. M. 2016. Worker Protection Standard: Training Workers and Handlers under the 2016 Revision Requirements. PI-268. Gainesville: University of Florida Institute of Food and Agricultural Sciences. https://edis.ifas.ufl.edu/ pi268.

US EPA. 2016. How to Comply with the 2015 Revised Worker Protection Standard for Agricultural Pesticides: What Owners and Employers Need to Know. EPA 735-B-16-001. United States Environmental Protection Agency. https://www.epa.gov/pesticide-worker-safety/ pesticide-worker-protection-standard-how-comply-manual. 
Table 1. Suggested employee training verification record.

\section{Verification of Worker Protection Standard Safety Training}

Trainer's name:

Trainer qualifications:

$\square$ Certified applicator of restricted use pesticides (License number: )

$\square$ Designated as trainer by State/Tribe/EPA

$\square$ Completed a WPS Train-the-Trainer program approved by State/Tribe/EPA

Date of training: ( $\mathrm{mm} /$ day/year)

Type of training:

$\square$ Worker

$\square$ Handler

Training materials used and EPA approval number:

1.

2.

3.

4.

5.

Employee name

Employee signature

1.

2.

3.

4.

5.

6.

7.

8.

9.

10.

11.

12

Additional pages can be added.

This record must be retained for two years from the date of training. 